\title{
Pemanfaatan Potensi Lokal Ubi Jalar dan Labu Kuning untuk Meminimalisasi Penggunaan Tepung Gandum dalam Pembuatan Aneka Kue
}

\section{(Utilization Local Potential of Sweet Potatoes and Pumpkin to Minimize the Use of Wheat Flour in Making Various Cakes)}

\author{
Andi Nur Faidah Rahman*, Mulyati Muhammad Tahir, Jumriah Langkong \\ Program Studi Ilmu dan Teknologi Pangan, Departemen Teknologi Pertanian, Fakultas Pertanian, Universitas Hasanuddin, \\ Jl. Perintis Kemerdekaan KM.10, Tamalanrea Indah, Kec. Tamalanrea, Kota Makassar 90245. \\ Penulis Korespondensi: faidah83@yahoo.com \\ Diterima Agustus 2018/Disetujui Juli 2019
}

\begin{abstract}
ABSTRAK
Kabupaten Takalar merupakan salah satu daerah di Sulawesi Selatan dengan produk unggulannya adalah ubi jalar. Produksi ubi jalar di daerah ini cukup melimpah tetapi belum termanfaatkan dengan baik. Kegiatan pengabdian ini bertujuan untuk memanfaatkan potensi lokal yang melimpah dalam pembuatan aneka kue untuk meminimalisasi penggunaan tepung gandum. Metode yang digunakan adalah penyuluhan dan pelatihan. Kegiatan dilakukan di Kampung Tala, Kelurahan Sombalabella, Kecamatan Pattalassang, Kabupaten Takalar. Peserta berjumlah 25 orang yang terdiri dari pedagang kue dan ibu-ibu rumah tangga yang tidak produktif secara ekonomi. Kegiatan dilakukan dengan dua sesi, yaitu penyampaian materi dan praktik. Berdasarkan hasil kuisioner peserta terlihat peningkatan pengetahuan peserta sebesar $80 \%$, peserta telah mengetahui cara memanfaatkan potensi ubi jalar dan labu kuning yang ada di daerah mereka agar dapat bernilai ekonomi lebih tinggi. Selain itu terjadi peningkatan keterampilan peserta sebesar $92 \%$ dalam mengolah ubi jalar dan labu kuning menjadi aneka kue seperti donat, panada, dan roti goreng serta peserta terampil dalam mengemas produk dengan kemasan plastik vakum dan non vakum. Kegiatan pengabdian kepada masyarakat ini dari sisi ekonomi dapat meningkatkan pendapatan masyarakat dan dari sisi kesehatan dapat menambah nilai gizi masyarakat dari aneka kue yang dihasilkan.
\end{abstract}

Kata kunci: Kelurahan Sombalabella, nilai gizi, pengemasan vakum

\section{ABSTRACT}

Takalar District is one of the areas in South Sulawesi with its superior product that is sweet potato. Sweet potato production in this area is quite abundant but has not been utilized properly. This activity aimed to utilize the abundant local potential in making various cakes to minimize the use of wheat flour. The method used was counseling and training. The activity was carried out in Tala, Sombalabella Village, Pattalassang Subdistrict, Takalar District. Participants amount are 25 peoples consisting of cake traders and housewives who are not economically productive. The activity was carried out with two sessions, that is material present and practice. Based on the results of participant's questionnaires, there was an increase in the knowledge of the participants up to $80 \%$, the participants already knew how to utilize the potential of sweet potatoes and pumpkin in their area to have higher economic value. In addition there was an increase in the skills of the participants up to $92 \%$ in processing sweet potatoes and pumpkin into a variety of cakes such as donuts, panada, and fried bread as well as participants skilled in packaging products with vacuum and non-vacuum plastic packaging. Community service activities from the economic side can increase people's income, and from the health side can add the nutritional value of the community from that various cakes produced.

Keywords: nutritional value, Sombalabella Village, vacuum packaging

\section{PENDAHULUAN}

Kabupaten Takalar merupakan sebuah kabupaten yang berada di Provinsi Sulawesi Selatan, Indonesia. Ibukota Kabupaten Takalar terletak di Pattallassang. Kabupaten Takalar terdiri dari sembilan kecamatan, yaitu Pattallassang, Polombangkeng Selatan, Polombangkeng Utara, Galesong, Galesong Selatan, Galesong Utara, Mappakasunggu, Sanrobone, dan Manggarabombang. Kabupaten ini memiliki luas wilayah $566,51 \mathrm{~km}^{2}$. Jarak 
Kabupaten Takalar dengan Provinsi Sulawesi Selatan adalah $45 \mathrm{~km}$ melalui Kabupaten Gowa dan berpenduduk sebanyak 289.978 jiwa pada tahun 2016. Berdasarkan data potensi pertanian Kabupaten Takalar, menunjukkan bahwa produk unggulan daerah salah satunya adalah umbiumbian seperti ubi jalar, dengan produksi pada tahun 2016 sebesar 4.419 ton dari 301/ha dengan produktivitas 14,67 ton/ha (Data BPS Kabupaten Takalar 2017). Sedangkan, labu kuning masih ditanam di kebun, pekarangan ataupun dilakukan secara tumpang sari. Karena labu kuning merupakan tanaman yang serumpun dengan buah semangka, maka labu kuning sangat cocok untuk dibudidayakan di Kabupaten Takalar yang merupakan daerah penghasil buah semangka yang sangat baik, yakni 1.850 ton (Data BPS Kabupaten Takalar 2017).

Ubi jalar dan labu kuning mengandung nilai gizi yang lengkap. Selain sebagai sumber serat, protein, karbohidrat, lemak, dan mineral, ubi jalar dan labu kuning juga mengandung antioksidan (beta karoten) yang tinggi yang berasal dari warna kuning ubi jalar dan warna kuning labu (Fitriyah \& Baharuddin 2016). Menurut Kandlakunta et al. (2008) labu kuning mengandung beta karoten sebesar 1,18 mg/100g, sedangkan menurut Balitkabi (2016), ubi jalar kuning varietas papua solossa mengandung beta karoten sebesar 0,534 mg/100g. Adapun komposisi kimia labu kuning menurut United States Department of Agriculture (USDA) adalah protein sebesar $1 \mathrm{~g}$, karbohidrat sebesar 6,5 g, gula sebesar 2,76 g, serat sebesar $0,5 \mathrm{~g}$, lemak sebesar 0,1 g, vitamin sebesar B1 0,05 mg, vitamin $C$ sebesar $9 \mathrm{mg}$, dan beberapa mineral seperti kalsium sebesar $21 \mathrm{mg}$, kalium sebesar $340 \mathrm{mg}$, fosfor sebesar $44 \mathrm{mg}$, magnesium sebesar $12 \mathrm{mg}$, dan besi sebesar 0,8 mg (Ashari 1995). Komposisi gizi ubi jalar berdasarkan warna daging umbi dapat dilihat pada Tabel 1 (Ginting et al. 2011).

Selain itu ubi jalar dan labu kuning mengandung pati yang tinggi sehingga dapat di- manfaatkan untuk meminimalisasi penggunaan tepung gandum dalam pembuatan aneka kue. Kadar pati ubi jalar berdasarkan daging umbinya adalah 28, 79\% (ubi jalar putih), 24,47\% (ubi jalar kuning), dan 22,64\% (ubi jalar ungu) (Ginting et al. 2011). Sedangkan, kadar pati labu kuning adalah 31,52\% (Budiman et al. 1984)

Pemanfaatan ubi jalar dan labu kuning di Kabupaten Takalar masih sebatas dibuat kue, kolak, dan sayur, sehingga produksi ubi jalar dan labu kuning yang melimpah tidak didukung oleh pemanfaatan yang maksimal dan berakibat pada penurunan kualitas akibat penyimpanan yang lama dan harga jualnya pun menurun dengan lamanya waktu penyimpanan. Berdasarkan hasil survei, masyarakat di Kabupaten Takalar umumnya menyukai aneka kue gorengan. Kue gorengan seperti donat, panada, dan roti goreng umumnya diperjualbelikan oleh masyarakat setempat guna menambah penghasilan. Umumnya mereka membuat aneka gorengan dengan menggunakan tepung gandum $100 \%$, sehingga membutuhkan modal bahan baku yang lebih besar. Selain itu, kue-kue yang dihasilkan tidak bertahan lama, yaitu hanya sampai 2 hari saja.

Pengolahan ubi jalar dan labu kuning menjadi aneka kue seperti cake (Loelianda et al. 2017), muffin (Damayanti et al. 2018), flake (Purnamasari \& Putri 2015), dan mi kering (Safriani et al. 2015) telah banyak diteliti. Dan berdasarkan hasil penelitian menunjukkan bahwa penambahan ubi jalar dan labu kuning pada pembuatan kue dan mi dapat meningkatkan nilai gizi dan nilai sensori seperti warna, rasa, aroma, dan tekstur dari produk yang dihasilkan.

Bertitik tolak dari hal tersebut tim berinisiatif mengajarkan pedagang kue dan ibu-ibu rumah tangga yang tidak produktif secara ekonomi di Kecamatan Pattalassang, Kelurahan Sombalabella untuk memanfaatkan potensi hasil pertanian mereka dalam meminimalisasi penggunaan tepung gandum untuk membuat aneka kue seperti kue donat, panada, dan roti goreng,

Tabel 1 Komposisi gizi ubi jalar berdasarkan warna daging buah

\begin{tabular}{lccc}
\hline \multicolumn{1}{c}{ Komposisi } & Ubi jalar putih & Ubi jalar kuning & Ubi jalar ungu \\
\hline Gula reduksi (\%) & 0,32 & 24,47 & 0,30 \\
Lemak (\%) & 0,77 & 0,11 & 0,94 \\
Protein (\%) & 0,89 & 0,68 & 0,77 \\
Air (\%) & 62,24 & 0,49 & 70,46 \\
Kadar Abu (\%) & 0,93 & 68,78 & 0,84 \\
Serat (\%) & 2,79 & 0,99 & 3,00 \\
Vitamin C (mg/100g) & 28,68 & 2,79 & 21,43 \\
Antosianin (mg/100g) & - & - & 110,51 \\
\hline
\end{tabular}


yang merupakan aneka kue yang sering diperjualbelikan di daerah tersebut. Selain itu tim juga mengajarkan bagaimana mempertahankan tekstur kue yang dibuat agar tidak cepat kering dengan aplikasi teknologi kemasan.

\section{METODE PELAKSANAAN KEGIATAN}

\section{Lokasi dan Sasaran Program}

Lokasi pengabdian kepada masyarakat adalah di Kampung Tala, Kelurahan Sombalabella, Kecamatan Pattalassang, Kabupaten Takalar, dengan kelompok sasaran program adalah pedagang kue dan ibu-ibu rumah tangga yang tidak produktif secara ekonomi.

\section{Waktu Pelaksanaan}

Kegiatan pengabdian dalam bentuk penyuluhan dan pelatihan telah dilakukan pada tanggal 11 Agustus 2018. Kegiatan dilakukan di balai Kelurahan Sombalabella, Kabupaten Takalar dengan mengundang pedagang kue dan ibu-ibu rumah tangga yang tidak produktif secara ekonomi. Kegiatan dilaksanakan dalam dua sesi, yaitu sesi pertama penyampaian materi mengenai potensi pemanfaatan ubi jalar dan labu kuning, serta tatacara pengolahan ubi jalar dan labu kuning menjadi aneka kue dan bagaimana mempertahankan tekstur kue yang dihasilkan agar tidak cepat mengeras. Sesi kedua kegiatan adalah praktik membuat aneka kue (donat, panada, dan roti goreng) dan praktik mengemas kue dengan kemasan vakum dan non-vakum. Setelah kegiatan selesai, kemudian dilakukan monitoring hasil kegiatan untuk mengecek dampak dari pelaksanaan kegiatan kepada peserta.

\section{Bahan dan Alat}

Bahan-bahan yang digunakan dalam pelaksanaan kegiatan adalah labu kuning (Cucurbita moschulata) dan ubi jalar kuning (Ipomoea batatas L.) yang dibeli di pasar tradisional Kabupaten Takalar, kemasan vakum, oxygen adsorber, tepung terigu, dan bahan-bahan pendukung pembuatan adonan kue. Alat-alat yang digunakan adalah alat pengemas vakum, penggiling adonan, dan alat-alat masak.

\section{Metode Pelaksanaan Kegiatan}

Kegiatan pengabdian ini dilakukan dalam tiga tahap, yaitu tahap persiapan, pelaksanaan, dan pengumpulan data dari hasil monitoring setelah kegiatan dilaksanakan.

\section{- Tahap persiapan}

Pada tahap ini dilakukan koordinasi antara mitra program, yaitu lembaga pengabdian masyarakat (LPM) Kelurahan Sombalabella dan tim pengabdian kepada masyarakat Universitas Hasanuddin dalam mempersiapkan pelatihan yang meliputi persiapan peserta pelatihan, waktu dan tempat pelatihan yang akan diadakan di balai Kelurahan Sombalabella, dan peralatan yang akan digunakan dalam pelatihan.

\section{- Tahap pelaksanaan}

Pelaksanaan kegiatan ini diawali dengan pembuatan modul pelatihan untuk dibagikan kepada peserta pelatihan. Kegiatan pelatihan meliputi: 1) Penyampaian materi dan diskusi, peserta diberikan modul sebagai panduan dalam membuat aneka kue dari ubi jalar dan labu kuning; 2) Praktik mengolah ubi jalar dan labu kuning menjadi aneka kue (donat, panada, dan roti goreng); dan 3) Praktik mengemas dengan plastik non-vakum dan plastik vakum untuk mempertahankan tekstur kue agar tidak cepat keras.

\section{- Tahap pengumpulan data}

Metode pengumpulan data pada kegiatan ini dilakukan melalui metode survei menggunakan kuesioner dan wawancara langsung dengan peserta. Peserta diminta mengisi kuesioner sebelum dan setelah kegiatan dilaksanakan. Kuesioner berisi beberapa pertanyaan untuk mengecek dampak kegiatan terhadap masyarakat yang dilibatkan.

\section{HASIL DAN PEMBAHASAN}

\section{Tahap Koordinasi}

Kegiatan koordinasi merupakan salah satu tahap persiapan sebelum melaksanakan kegiatan penyuluhan dan pelatihan. Setelah mendapat izin dari kepala Kelurahan Sombalabella, pihak lembaga pengabdian mayarakat (LPM) Kelurahan Sombalabella dan tim pengabdian kepada masyarakat Universitas Hasanuddin melakukan koordinasi untuk mengatur proses pelaksanaan kegiatan yang meliputi persiapan tempat di balai Kelurahan Sombalabella, peserta penyuluhan dan pelatihan yang berada di sekitar Kelurahan, dan waktu pelaksanaan kegiatan yang disepakati.

\section{Pelaksanaan Program}

Kegiatan pengabdian dalam bentuk penyuluhan dan pelatihan telah dilakukan di Kelurahan 
Sombalabella, Kecamatan Pattalassang, Kabupaten Takalar pada tanggal 11 Agustus 2018. Kegiatan dilaksanakan dengan mengundang pedagang kue dan ibu-ibu rumah tangga yang tidak produktif secara ekonomi sebanyak 25 orang. Sebelum kegiatan dimulai, peserta dibagikan kuesioner yang berisi beberapa pertanyaan yang berkaitan dengan kegiatan pengabdian. Kegiatan dilaksanakan dalam dua sesi, yaitu kegiatan penyuluhan dan kegiatan pelatihan.

Sebelum kegiatan penyuluhan dilaksanakan dilakukan pembagian modul panduan. Modul panduan berisi informasi tentang potensi dan manfaat ubi jalar dan labu kuning, cara mengolahnya menjadi aneka kue agar bernilai ekonomi lebih tinggi, dan cara mempertahankan tekstur kue agar tidak cepat keras. Kegiatan penyuluhan dilakukan dengan cara penyampaian materi oleh tim pengabdian dan diskusi dengan peserta penyuluhan (Gambar 1).

Kegiatan pelatihan dilakukan dalam dua tahap. Tahap pertama praktik mengolah ubi jalar dan labu kuning menjadi aneka kue (praktik membuat adonan, pembentukan, pengisian, dan penggorengan) yang dilakukan di balai Kelurahan Sombalabella (Gambar 2). Peserta pelatihan diminta membuat adonan kue dari ubi jalar dan labu kuning. Adonan dibuat menjadi beberapa aneka kue yang biasa diperjualbelikan di daerah setempat seperti donat, panada, dan roti goreng. Penambahan ubi jalar dan labu kuning dalam pembuatan adonan kue dapat meningkatkan nilai gizi dan nilai sensori seperti tekstur, rasa, aroma dan warna dari produk yang dibuat (Purnamasari \& Putri 2015; Safriani et al. 2015; Loelianda et al. 2017; Damayanti et al. 2018). Masyarakat atau peserta pelatihan sangat antusias mengikuti kegiatan ini.

Tahap kedua praktik mengemas kue dengan teknologi kemasan vakum dan kemasan nonvakum agar tekstur kue tidak cepat keras (Gambar 3). Aneka kue yang telah dibuat dikemas dengan plastik non-vakum dan plastik vakum. Tujuan dari pengemasan adalah untuk mempertahankan tekstur kue agar tidak cepat keras. Selain itu penggunaan kemasan dapat menjaga kebersihan kue yang dibuat. Menurut Buckle et al. (1987) pengemasan dapat mempertahankan mutu pangan dalam jangka waktu yang diinginkan. Keuntungan penggunaan kemasan plastik pada bahan pangan yang dikemas adalah dapat melindungi produk terhadap cahaya, udara atau oksigen, dan kontaminasi. Selain itu plastik juga dapat mengurangi kehilangan sejumlah air dan lemak pada produk sehingga produk tidak

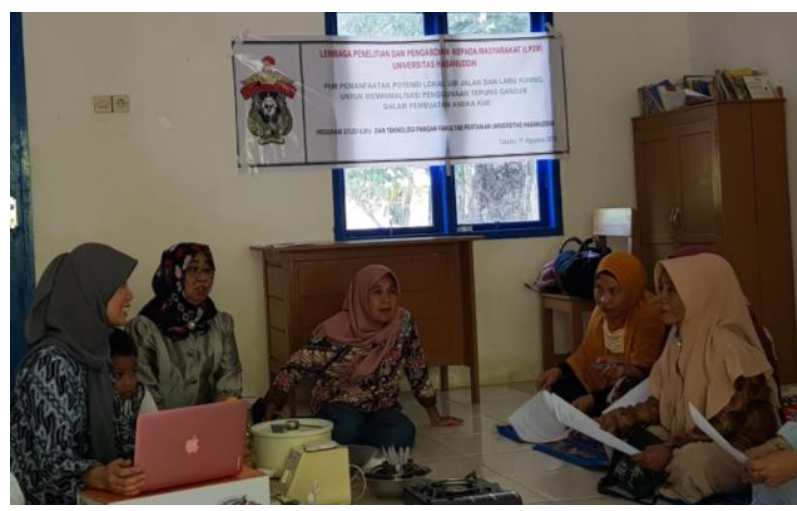

Gambar 1 Penyampaian materi dan diskusi.
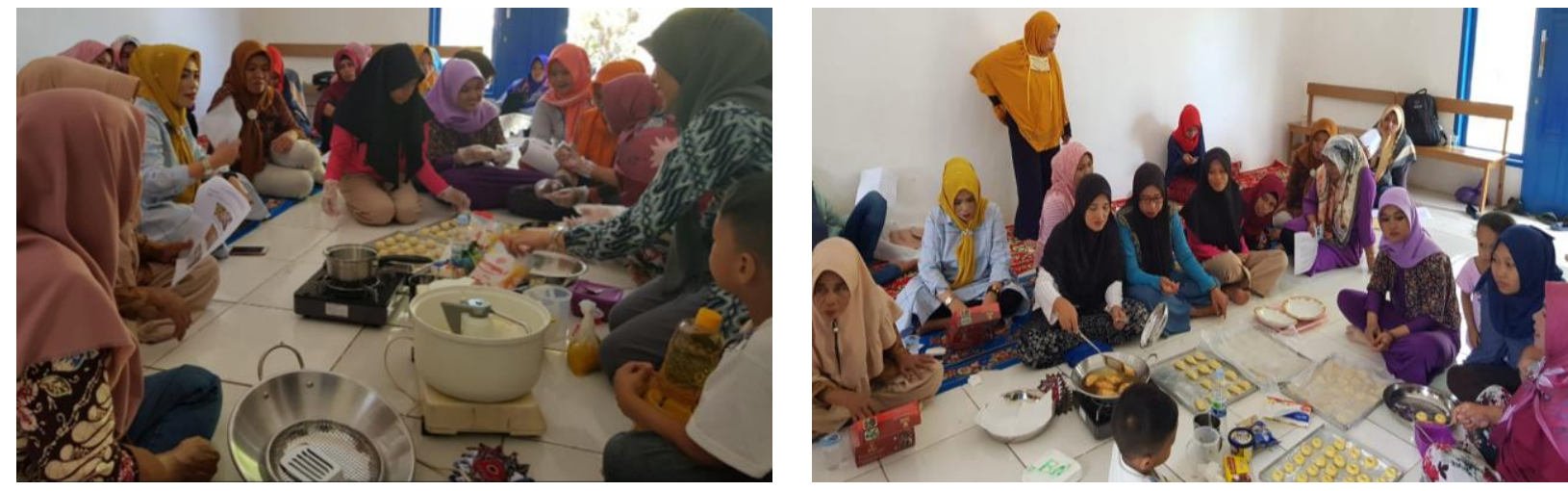

Gambar 2 Praktik membuat adonan dengan penambahan ubi jalar dan labu kuning. 
mudah, mengeras. Menurut Syarief et al. (1989) penggunaan plastik pada pangan cukup menguntungkan karena mudah dibentuk, mempunyai adaptasi yang tinggi terhadap produk, tidak korosif seperti wadah logam, serta mudah dalam penanganannya. Sementara itu, penggunaan teknologi pengemasan vakum bertujuan untuk menambah umur simpan produk dengan jalan mengeluarkan oksigen dari kemasan, sehingga pertumbuhan organisme aerobik di dalam kemasan dapat ditekan (Sacharow \& Griffin 1978).

\section{Tahap Monitoring Hasil Kegiatan}

\section{- Kegiatan penyuluhan}

Kegiatan monitoring dilakukan oleh tim berdasarkan hasil kuesioner yang telah diisi oleh peserta sebelum dan sesudah kegiatan dilaksanakan. Keberhasilan kegiatan penyuluhan dapat dilihat dari peningkatan pengetahuan dari tidak tahu menjadi tahu dan dari tahu menjadi lebih tahu, peningkatan keterampilan dari tidak mampu menjadi mampu, peningkatan sikap dari tidak mau menjadi mau (Ibrahim 2003). Gambar 4 menunjukkan terjadi peningkatan pengetahuan masyarakat mengenai potensi lokal (ubi jalar dan labu kuning) yang berada di daerah mereka untuk dapat dimanfaatkan dalam mengsubtitusi penggunaan tepung terigu dalam membuat aneka kue, sehingga dapat mengurangi biaya bahan baku. Selain itu, masyarakat juga sudah mengetahui bahwa penggunaan ubi jalar dan labu kuning dapat meningkatkan nilai gizi dan nilai sensori dari produk yang dihasilkan. Besarnya peningkatan pengetahuan masyarakat dari $12 \%$ atau 3 orang dari 25 orang peserta penyuluhan menjawab tahu sebelum kegiatan penyuluhan meningkat menjadi $92 \%$ atau 23 orang dari 25 orang peserta menjawab tahu. Hal ini menunjukkan bahwa kegiatan penyuluhan dapat dikatakan berhasil karena adanya peningkatan pengetahuan peserta penyuluhan.

\section{- Kegiatan Pelatihan}

Kegiatan pelatihan dilakukan dalam bentuk praktik. Peserta pelatihan didampingi oleh tim membuat aneka kue yang biasa diperjualbelikan di Kelurahan Sombalabella seperti donat, panada, dan roti goreng dari bahan baku ubi jalar dan labu kuning. Selain itu peserta juga mempraktikkan bagaimana mengemas produk yang dihasilkan dengan kemasan non-vakum dan kemasan vakum. Gambar 5 menunjukkan peningkatan keterampilan masyarakat dari tidak mampu
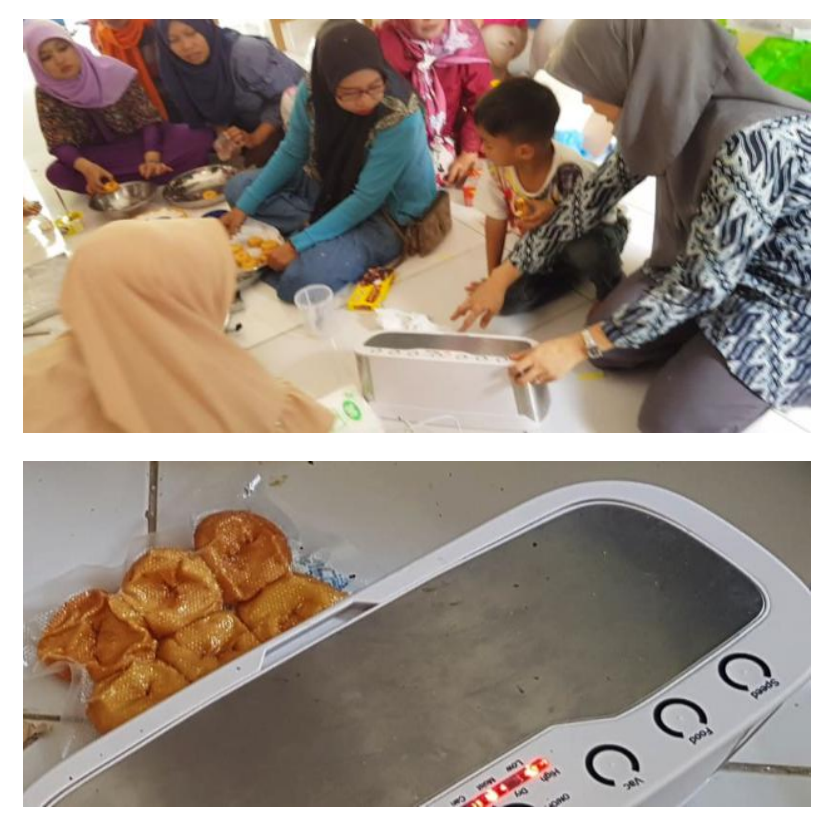

Gambar 3 Praktik mengemas dengan teknologi kemasan vakum dan non vakum.
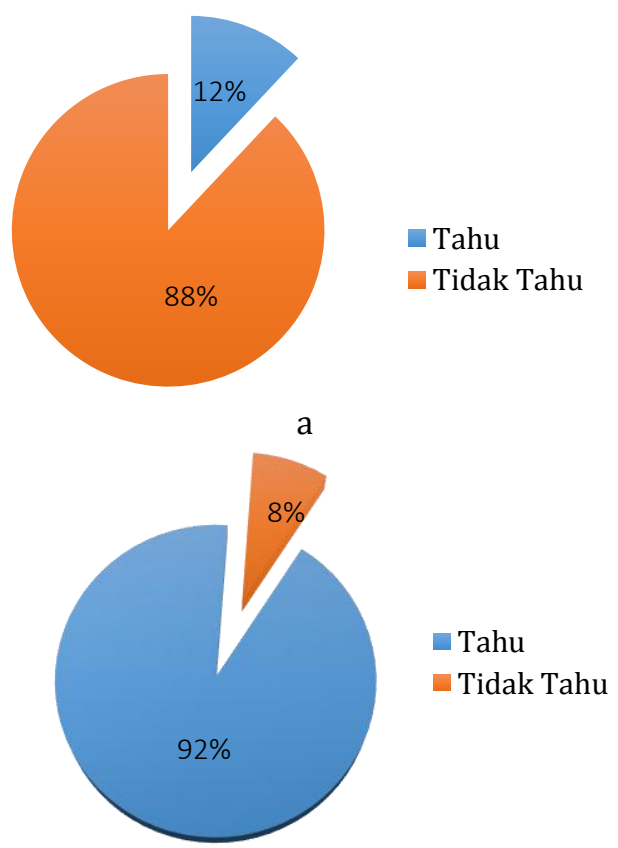

b

Gambar 4 Persentase hasil monitoring kegiatan penyuluhan sebelum (a) dan sesudah (b) kegiatan

menjadi mampu membuat kue dari subtitusi tepung terigu dengan ubi jalar dan labu kuning. Begitupun dalam mengemas kue dengan kemasan vakum dan non-vakum. Besarnya peningkatan keterampilan peserta, yaitu dari 8\% atau 2 orang dari 25 orang peserta pelatihan menjawab mampu sebelum dilakukan praktik meningkat menjadi $100 \%$ atau 25 orang dari 25 orang peserta yang mampu mempraktikkan cara membuat kue dari bahan baku ubi jalar dan labu 
kuning dan mampu mengemas kue yang dihasilkan baik dengan plastik vakum maupun non-vakum. Hal ini menunjukkan bahwa kegiatan pelatihan dalam bentuk praktik dapat dikatakan berhasil karena terjadi peningkatan kemampuan peserta dalam mempraktikkan materi yang diberikan.

\section{Luaran yang Dihasilkan}

Kegiatan penyuluhan dan pelatihan yang diadakan di Kelurahan Sombalabella, Kabupaten Takalar, Sulawesi Selatan, menghasilkan beberapa luaran, yaitu 1) Diversifikasi produk dari ubi jalar dan labu kuning seperti donat, panada, dan roti goreng (Gambar 6); 2) Peningkatan kualitas produk seperti meningkatnya nilai gizi dan nilai sensori dari produk yang dihasilkan. Hal ini mengacu pada beberapa hasil penelitian yang telah dilakukan Purnamasari \& Putri 2015; Safriani et al. 2015; Loelianda et al. 2017; Damayanti et al. 2018 dengan mengsubtitusi penggunaan tepung terigu dengan ubi jalar dan labu kuning dalam membuat aneka produk; dan 3) Berdasarkan hasil monitoring kegiatan pelatihan dengan metode pengisian kuesioner bahwa pengetahuan dan keterampilan masyarakat bertambah setelah mengikuti pelatihan ini. Pengetahuan masyarakat tentang potensi dan manfaat ubi jalar dan labu kuning dalam pembuatan aneka kue meningkat dari $12 \%$ menjadi 92\% dan keterampilan peserta dalam mengemas produk (kue) yang dihasilkan dengan plastik vakum maupun non-vakum meningkat dari $8 \%$ menjadi $100 \%$.

\section{SIMPULAN}

Kegiatan pelatihan yang dilaksanakan di Kampung Tala, Kelurahan Sombalabella, Kecamatan Pattalassang, Kabupaten Takalar mendapat respons yang baik dari masyarakat, dan dikatakan berhasil karena dapat meningkatkan pengetahuan peserta sebesar $80 \%$ tentang potensi dan manfaat ubi jalar dan labu kuning dalam pembuatan aneka kue dan meningkatkan kemampuan keterampilannya sebesar 92\% dalam membuat ane kue (donat, panada, dan roti goreng) dengan bahan baku dari ubi jalar dan labu kuning, serta meningkatkan keterampilan peserta dalam mengemas produk (kue) yang dihasilkan dengan plastik vakum maupun non-vakum.

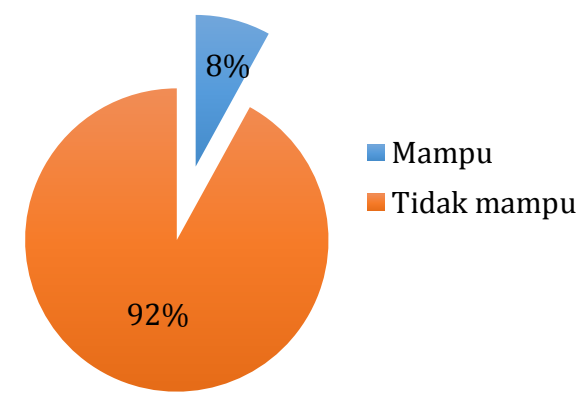

a

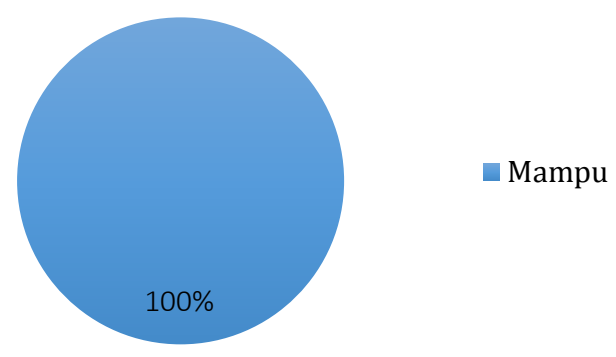

b

Gambar 5 Persentase hasil monitoring kegiatan pelatihan sebelum (a) dan sesudah (b) kegiatan

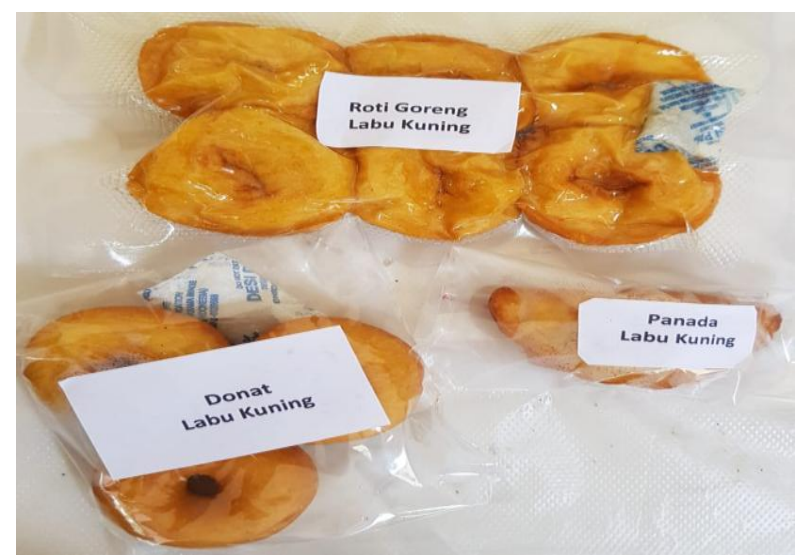

Gambar 6 Diversifikasi produk dari ubi jalar dan labu kuning.

\section{DAFTAR PUSTAKA}

Ashari S. 1995. Hortikultura Aspek Budidaya. Jakarta (ID): UI Press.

[Balitkabi] Balai Penelitian Tanaman Aneka Kacang dan Umbi. 2016. Deskripsi Varietas Unggul Aneka Kacang dan Umbi. [Internet]. Diakses pada: Juli 2019. Tersedia pada http://balitkabi.litbang.pertanian.go.id/publi kasi/deskripsi-varietas/.

Budiman L, Soekarto ST, Apriyantono A. 1984. Karakteristik Buah Labu (Cucurbita pepo L.). Buletin Penelitian Ilmu dan Teknologi Pangan. 3: 116-135. 
Buckle KA, Edwards RA, Fleet GH, Wooton. 1987. Ilmu Pangan. Terjemahan. Jakarta (ID): UIPress.

Damayanti DS, Rusmin M, Hardiyanti SM. 2018. Analisis Kandungan Zat Gizi Muffin Ubi Jalar Kuning (Ipomoea batatas L.) sebagai Alternatif Perbaikan Gizi Masyarakat. Public Health Science Journal. 10(1): 108-119.

Fitriyah AT, Baharuddin. 2016. Potensi Pemanfaatan Agroindustri Waluh Kuning sebagai Peluang Usaha dan Makanan Kesehatan. Jurnal Ecosystem. 16(3): 407-419.

Ginting E, Utomo JS, Yulifianti R, Yusuf M. 2011. Potensi Ubi Jalar Ungu sebagai Pangan Fungsional. Iptek Tanaman Pangan. 6(1): 116-138.

Ibrahim SA. 2003. Eliminating Health Inequalities. American Journal of Public Health. 93(10): 16-18. https://doi.org/10.2105/ AJPH.93.10.1618

Kandlakunta B, Rajendran A, Thingnganing L. 2008. Carotene Content of Some Common (Cereals, Pulses, Vegetables, SpIces and Condiments) and Unconventional Sources of Plant Origin. Food Chemistry. 106(1): 85-89. https://doi.org/10.1016/j.foodchem.2007.05
.071

Loelianda P, Nafi A, Windrati WS. 2017. Subtitusi Tepung Labu Kuning (Cucurbita moschata Durch) dan Koro Pedang (Canavalia ensiformis L.) terhadap Terigu pada Pembuatan Cake. Jurnal Agroteknologi. 11(1): 45-54. https:// doi.org/10.19184/j-agt.v11i1.5444

Purnamasari IW, Putri WDR. 2015. Pengaruh Penambahan Tepung Labu Kuning dan Natrium Bikarbonat terhadap Karakteristik Flake Talas. Jurnal Pangan dan Agroindustri. 3(4): 1375-1385.

Pemerintah Kabupaten Takalar. 2017. Kabupaten Takalar dalam Angka. Badan Pusat Statistik (BPS) Kabupaten Takalar.

Sacharow S, Griffin RC. 1978. Food Packaging. Texas (USA): Avi Publishing Co Inc.

Safriani N, Husna NE, Rizkya R. 2015. Pemanfaatan Pasta Labu Kuning (Cucurbita moschata) pada Pembuatan Mie Kering. Jurnal Agroindustri. 5(2): 85-94. https://doi.org/ 10.31186/j.agroind.5.2.85-94

Syarief R, Santausa S, Isyana ST. 1989. Teknologi Pengemasan Pangan. Laboratorium Rekayasa Proses Pangan, PAU Pangan dan Gizi. Bogor (ID): Institut Prtanian Bogor. 